\title{
Demonstration of BMP's in Sunflower for Sustainable Yields under Black Soil Tracts of Rayalaseema Region of Andhra Pradesh, India
}

\author{
Madaka Madhan Mohan*, S. Ramalakshmi Devi and A. Veeraiah \\ Krishi Vigyan Kendra, Utukur, Y.S.R District, A.P, India \\ *Corresponding author
}

\begin{abstract}
A B S T R A C T
\section{Keywords}

Best Management

Practices, Cluster

front line

demonstrations,

Integrated nutrient management

\section{Article Info}

Accepted:

25 August 2019

Available Online:

10 September 2019

Cluster front line demonstrations were organized in sunflower crop under NMOOP-2016 to enhance the productivity and profitability by demonstrating Best Management Practices (BMP's) about 24 ha area in farmer's fields of KVK operational villages namely Kumarampalli village of Vempalli mandal and Jogireddypalli of Chakrayapeta mandal of Y.S.R district of Andhra Pradesh through participatory approach. KVK scientists demonstrated the BMP's viz., Sowing of only two seeds per hill under Ridge and furrow system; Adopted Integrated Nutrient Practices viz., 75-90-30 N- $\mathrm{P}_{2} \mathrm{O}_{5}-\mathrm{K}_{2} \mathrm{O}$, Neem cake powder @ $500 \mathrm{~kg} / \mathrm{ha}$, PSB @ $5 \mathrm{~kg} / \mathrm{ha}$, Sulphur granules @ $25 \mathrm{~kg} / \mathrm{ha}$, Boron @ $5 \mathrm{~kg} / \mathrm{ha}$ and Zinc (12\%) @ 2.25 kg/ha; Soil Application of Trichoderma viride @ $2.5 \mathrm{~kg} / \mathrm{ha}$ to prevent fungal diseases; Maintained optimum Crop stand by adopting Thinning practice at 15 DAS by keeping one seedling per hill; Adopted Integrated management practices for the management of Necrosis viral disease viz., Border crop with four rows of Jowar, Parthenium eradication around the demonstrated fields on participatory approach and Vector control by spraying Monocrotophos @ $1.6 \mathrm{ml} /$ lit at 20, 40 DAS and Imidachloprid @ $0.4 \mathrm{ml} /$ lit at 50 DAS; Prophylactic spraying of Hexaconazol @ $2 \mathrm{ml} /$ lit for Alternaria leaf spot against farmer's cultivation practices namely sowing 4-5 seeds per hill, complex fertilizer (28-28-0) application, no border crop and no pesticide sprays up to 60DAS etc. The average yield of $1371 \mathrm{~kg} / \mathrm{ha}$ was recorded in demonstration practice and which is 30.5 percent higher than the farmer's cultivation practice and also 69.8 percent and 110 percent higher than the district $(809 \mathrm{~kg} / \mathrm{ha})$ and state average productivity $(650 \mathrm{~kg} / \mathrm{ha})$ respectively. The highest net returns of Rs 15985/- per ha was recorded in demonstration practice against loss of Rs.6151/- per ha by farmer's practice and also Rs. 7500/- per ha was saved by adoption of BMP's versus farmers practice of sunflower cultivation.
\end{abstract}

\section{Introduction}

Sunflower is major oil seed crop being grown in the district because of its short duration and photo insensitive in nature and hence it has wider adoptability as a catch crop during the period when the land is otherwise fallow in black soil tracts of Rayalaseema districts of Andhra Pradesh. Sunflower oil is a rich source of linoleic acid (64\%) and it is good for heart patients and hence it can play an important role in meeting out the shortage of edible oil requirement of our country. Globally sunflower is cultivated over an area of 23.71 
$\mathrm{M}$ ha with the production of $32.39 \mathrm{Mt}$ and productivity of $1,366 \mathrm{~kg} \mathrm{ha}^{-1}$ that accounts for nearly $8.5 \%$ of total world's oilseeds production (Nayak et al., 2010). The average sunflower productivity in India is low, i.e. around $607 \mathrm{~kg}$ ha-1 (Hegde, 2012). In India, sunflower is being cultivated in the states of Karnataka, Maharashtra and Andhra Pradesh of which Karnataka alone accounts for nearly $54 \%$ of cultivated area. In these states, it is mainly cultivated in rainfed regions where average annual rainfall is less than $650 \mathrm{~mm}$ coupled with uneven distribution. At present the sunflower area is shrinking year by year causing worry to policy makers because of its production constraints like frequent drought spells, lack of awareness on balanced fertilization, soil test based fertilizer application and importance of thinning operation, border cropping, high incidence of necrosis and Alternaria leaf spot diseases, bird damage and finally lack of remunerative price compare to other oil seed crops made sunflower unattractive for farmers and diversified to bengalgram, castor, sesame etc in the district. But sunflower has the potential to yield at least $2,000 \mathrm{~kg} / \mathrm{ha}$ under rainfed and limited irrigation conditions with existing hybrids if crop is raised with Best Management Practices (BMP's).

It is therefore necessary to address the existing production constraints of sunflower by creating awareness among the farming community through capacity building programmes and front line demonstrations with technological interventions to enhance net returns and to prove the sunflower as remunerative. Krishi Vigyan Kendra's have village level network with Dept. of Agriculture meant for introducing the new technology through assessment, refinement and demonstration of proven technologies under different micro farming situation (Das, 2010). The main objective of cluster front line demonstration was to increase the sunflower productivity through improved crop management practices. The newly and innovative technology having higher production potential under the specific cropping system can be popularized among sunflower growing tracts of Y.S.R district through cluster approach.

The present study was undertaken to demonstrate the performance of Best Management Practices (BMP's) in sunflower cultivation under cluster front line demonstrations - NMOOP during 2015-16.

\section{Materials and Methods}

The present study was conducted in 24 ha area and 51 farmers holdings from KVK operational villages namely Kumarampalli village of Vempalli mandal and Jogireddypalli of Chakrayapeta mandal of Y.S.R district of Andhra Pradesh where the sunflower grown extensively during rabi season. The study area between $14^{0} 16^{\prime} 80^{\prime}$ ' $\mathrm{N}$ latitude \& $78^{\circ} 28^{\prime}$ 72 ' $E$ longitude and falls under semi arid type of climate with average annual rainfall of 710 mm mostly from south west monsoon period (June - September) and the soils are black soils having low inherent fertility status. The representative soil samples from demonstration fields were collected at $0-15 \mathrm{~cm}$ immediately after harvest of kharif crop and analyzed for soil fertility status by following standard procedures and recommended the fertilizers as per soil test values and the average soil fertility status and fertility recommendations based on soil test values are furnished in Table.1. The soils are slightly alkaline $(7.5-8.2)$ reaction, slightly saline $\left(0.10-0.18 \mathrm{~d} \mathrm{~S}^{-1} \mathrm{~m}^{-1}\right)$, low in available nitrogen $(110-162 \mathrm{~kg} / \mathrm{ha})$, medium to high in available phosphorous $(26.5-75.5 \mathrm{~kg} / \mathrm{ha})$ and available potassium $(160-375)$ and sulphur is deficient to sufficient in range $(4.0-22.5$ ppm). The best management practices in sunflower like Sowing of only two seeds per 
hill under Ridge and furrow system; Soil test based Integrated Nutrient Practices viz., 7590-30 N- $\mathrm{P}_{2} \mathrm{O}_{5}-\mathrm{K}_{2} \mathrm{O}$, Neem cake powder @ $500 \mathrm{~kg} / \mathrm{ha}$, PSB @ $5 \mathrm{~kg} / \mathrm{ha}$, Sulphur granules @ $25 \mathrm{~kg} / \mathrm{ha}$, Boron @ $5 \mathrm{~kg} / \mathrm{ha}$ and Zinc (12\%) ( $2.25 \mathrm{~kg} / \mathrm{ha} ;$ Soil Application of Trichoderma viride @ $2.5 \mathrm{~kg} / \mathrm{ha}$ against fungal diseases; Thinning practice at 15 DAS by keeping one seedling per hill to maintain optimum crop stand ; Adopted Integrated crop management practices for the management of Necrosis viral disease viz., 1. Border crop with four rows of Jowar, 2. Parthenium eradication around the demonstrated fields 3. Vector control by spraying Monocrotophos @ 1.6 ml/lit at 20, 40 DAS and Imidachloprid @ 0.4 $\mathrm{ml} / \mathrm{lit}$ at 50 DAS; Prophylactic spraying of Hexaconazol @ $2 \mathrm{ml} / \mathrm{lit}$ for Alternaria leaf spot at 70 DAS and shiny ribbon around the cultivated field were demonstrated against the farmer' cultivation practices namely more number of seeds per hill on flat bed method; only complex fertilizer application (28-28-0) without any other sulphur, boron and zinc fertilization; no border crop, prophylactic sprays against vector control and Parthenium around the fields and no measures for bird damage at maturity stage.

The demonstrated field was ploughed twice and levelled and prepared ridge and furrows with tractor drawn ridge former. The sunflower hybrid SIRI- 555 was sown by manual dibbling on the top side of the ridge with the spacing of $60 \mathrm{~cm} \mathrm{X} 30 \mathrm{~cm}$ and the crop sown during second F.N of January.

The extension gap, technology gap and the technology index for sunflower cultivation were worked out (Samui et al., 2000) as mentioned below:

Extension gap $=$ Demonstration yield farmers' yield (control)

Technology gap = Potential yield demonstration yield
Technology index = Potential Yield Demonstration Yield/ Potential Yield x 100

\section{Results and Discussion}

Under NMOOP -2015-16 provided the critical inputs and services viz., soil health cards of demonstrated fields, sulphur granules @ $5 \mathrm{~kg}$, Trichoderma viride@1 kg, PSB @ 2 kg, Borox@2 kg, chelated $\mathrm{ZnSO}_{4} @ 500 \mathrm{~g}$ and Imidachloprid@250 ml to the participatory farmers of both cluster villages. The demonstrated farmers applied chemical fertilizers as per the soil test values (Table.1) and boron, zinc sulphate were applied at basal only along with chemical fertilizers. $T$. viride multiplication was demonstrated through method demonstration and all demo farmers applied to soil after incubation of 15 days under shade during sowing. At 10 DAS scientists demonstrated the thinning operation by keeping only one seedling per hill instead of 3-4 seedlings per hill observed in farmer's practice.

Hence the crop was healthy and robust growth at initial vegetative stage in demonstrated field compared with farmer' practice by preventing the competition for nutrients, water among the seedlings and the application of soil test based fertilizer application reduced the cost to be spent on fertilizers, the sucking pest complex load especially white files was greatly reduced with prophylactic spraying of Monocrotophos @ $1.6 \mathrm{ml} / \mathrm{lit}$ at 20,40 DAS and Imidachloprid (a) $0.4 \mathrm{ml} /$ lit at $50 \mathrm{DAS}$ and thereby necrosis disease which is transmitted by white flies was managed effectively and affected plants of 2.0 to 5.0 percent observed in demonstration field, whereas in case of farmers practice affected plants up to 25 percent which caused 30 percent yield reduction compared to demonstration. Two hand weedings were carried out and maintained weed free during crop growth which further reduced the inoculum load for necrosis and Alternaria leaf 
spot diseases compared with farmer's practice. The head emergence was fast, complete and seed setting was very good at centre of head in demonstration practice compare to farmer's practice due to soil application of Borox @ 5 $\mathrm{kg} \mathrm{ha}^{-1}$. The low incidence of Alternaria leaf spot up to 5to 10 percent in demonstration practice where as it is up to 20 percent in farmer's practice. The bird damage was also minimised by erecting shiny ribbon around the demonstrated field compared to farmer's practice. By adoption of best management practices through demonstrations versus farmer's practice addressed the all production constraints resulted increased productivity and profitability by minimizing the cost incurred on fertilizers, seed and pesticides etc in sunflower. The average was recorded through demonstrations is $1371 \mathrm{~kg} \mathrm{ha}^{-1}$ with maximum of $2250 \mathrm{~kg} \mathrm{ha}^{-1} \&$ minimum of $912 \mathrm{~kg} \mathrm{ha}^{-1}$ which is 30.5 percent higher than farmer's practice $\left(952 \mathrm{~kg} \mathrm{ha}^{-1}\right)$ and 69.8 percent and 110 percent higher than the district (809 $\mathrm{kg} / \mathrm{ha})$ and state sunflower average productivity $(650 \mathrm{~kg} / \mathrm{ha})$ respectively.

Table.1 Average Initial soil fertility status and fertilizer recommendation based on soil test values in CFLD's sites

\begin{tabular}{|c|c|c|c|}
\hline S.No & Soil parameter & Range & $\begin{array}{l}\text { Fertilizer recommendation based on soil test } \\
\text { values }\end{array}$ \\
\hline 1 & Soil reaction $(\mathrm{pH})$ & $\begin{array}{l}7.5-8.2 \text { (slightly } \\
\text { alkaline) }\end{array}$ & -- \\
\hline 2 & $\begin{array}{l}\text { Electrical conductivity } \\
\left(\mathrm{d} \mathrm{S}^{-1} \mathrm{~m}^{-1}\right)\end{array}$ & $\begin{array}{l}0.10-0.18 \\
(\text { slightly alkaline })\end{array}$ & -- \\
\hline 3 & $\begin{array}{l}\text { Available nitrogen } \\
\left(\mathrm{kg} \mathrm{ha}^{-1}\right)\end{array}$ & $110-162($ Low $)$ & $\begin{array}{l}25 \text { percent higher than recommended nitrogen } \\
\left(87.5 \mathrm{~kg} \mathrm{ha}^{-1}\right) \text { was applied to the crop in three } \\
\text { splits: first split at sowing }(50 \%) \text {, second at } 30 \\
\text { DAS }(25 \%) \text { and third at bud formation stage }(25 \\
\%)\end{array}$ \\
\hline 4 & $\begin{array}{l}\text { Available Phosphorous } \\
\left(\mathrm{kg} \mathrm{ha}^{-1}\right)\end{array}$ & $\begin{array}{l}26.5-75.5 \\
\text { (medium to high) }\end{array}$ & $\begin{array}{l}\text { Recommended phosphorous }\left(90 \mathrm{~kg} \mathrm{ha} \mathrm{ha}^{-1}\right) \text { was } \\
\text { applied to the crop where soil having medium }(22 \\
-56 \mathrm{~kg} / \mathrm{ha}) \mathrm{P}_{2} \mathrm{O}_{5} \text { status, whereas, } 25 \% \text { higher than } \\
\text { recommended phosphorous }\left(112 \mathrm{~kg} \mathrm{ha}^{-1}\right) \text { applied } \\
\text { to soil having high }\left(>56 \mathrm{~kg} \mathrm{ha}^{-1}\right) \mathrm{P}_{2} \mathrm{O}_{5} \text { content }\end{array}$ \\
\hline 5 & $\begin{array}{l}\text { Available potassium } \\
(\mathrm{kg} / \mathrm{ha})\end{array}$ & $\begin{array}{l}160-375 \\
\text { (medium to high) }\end{array}$ & $\begin{array}{l}\text { Recommended potassium }\left(30 \mathrm{~kg} \mathrm{ha}^{-1}\right) \text { was applied } \\
\text { to the crop where soil having medium }(150-300 \\
\left.\mathrm{kg} \mathrm{ha}^{-1}\right) \mathrm{K}_{2} \mathrm{O} \text { status, whereas, } 25 \% \text { higher than } \\
\text { recommended potassium }\left(37.5 \mathrm{~kg} \mathrm{ha}^{-1}\right) \text { applied to } \\
\text { soil having high }\left(>300 \mathrm{~kg} \mathrm{ha}^{-1}\right) \mathrm{K}_{2} \mathrm{O} \text { content. }\end{array}$ \\
\hline 6 & Available sulphur (ppm) & $\begin{array}{l}4.0-22.5 \text { (low to } \\
\text { sufficient) }\end{array}$ & Applied $10 \mathrm{~kg}$ of sulphur granules to the crop \\
\hline 7 & $\begin{array}{l}\text { Micronutrients like Zinc } \\
\text { \& Boron }\end{array}$ & Deficient & $\begin{array}{l}\text { Soil application of Borox @ } 5 \mathrm{~kg} \mathrm{ha}^{-1} \text { and Zinc } \\
(12 \%) @ 2.25 \mathrm{~kg} \mathrm{ha}^{-1} \text { before sowing }\end{array}$ \\
\hline
\end{tabular}


Fig.1 Location map of the cluster front line demonstrations in sunflower with depiction of latitude and longitude of the study area

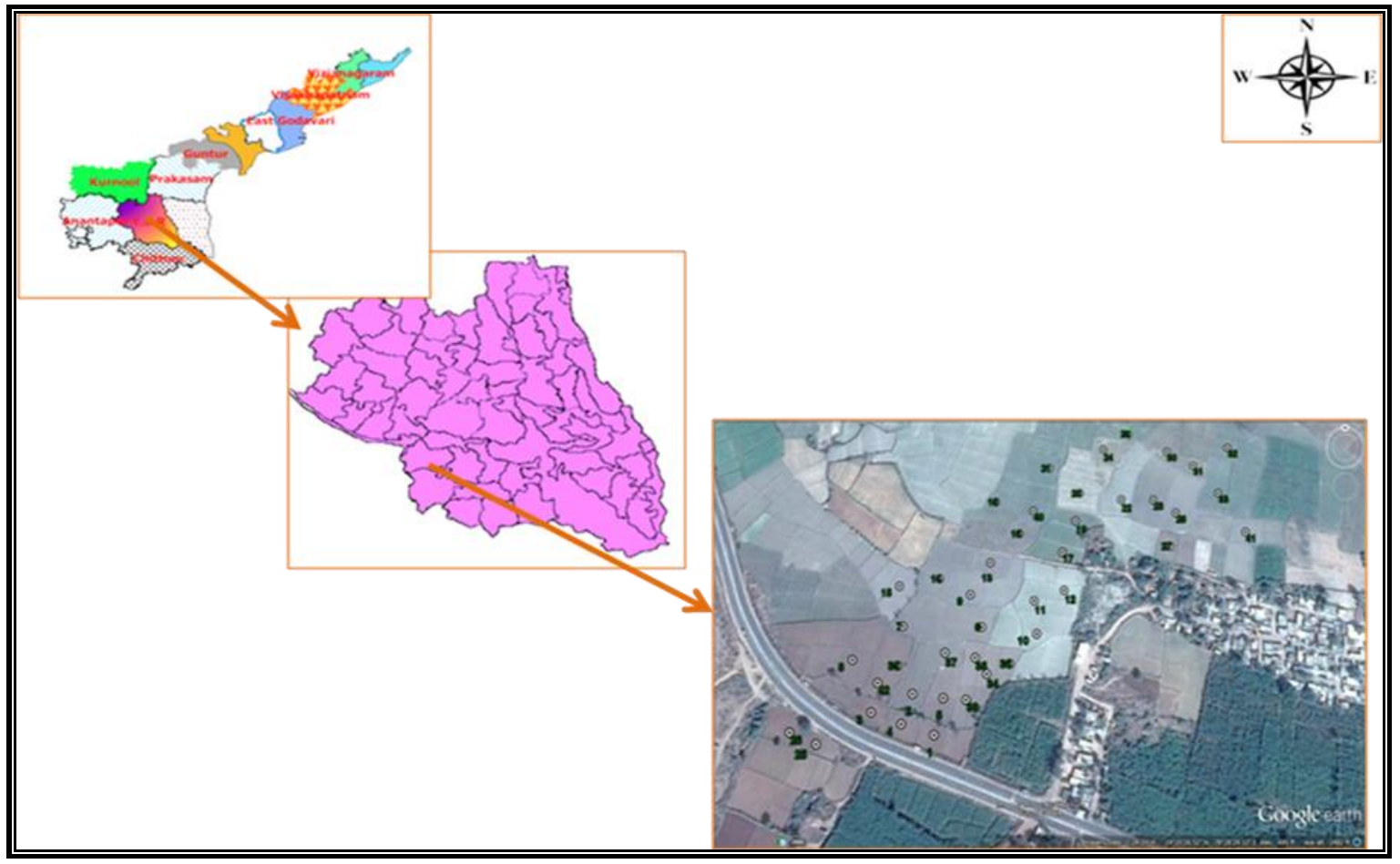

Table.2 Productivity of sunflower under demonstration and farmer's practice under Cluster front line demonstrations - NMOOP 2015-16

\begin{tabular}{|c|c|c|c|c|c|c|c|c|c|}
\hline S.No & Treatment $s$ & $\begin{array}{c}\text { Number } \\
\text { of } \\
\text { demonstr } \\
\text { ations }\end{array}$ & $\begin{array}{c}\text { Mean } \\
\text { Yield } \\
\left(\mathrm{kg} \mathrm{ha}^{-1}\right)\end{array}$ & $\begin{array}{c}\text { Mean } \\
\text { Gross } \\
\text { income } \\
\left(\text { Rs. ha }{ }^{-1}\right)\end{array}$ & $\begin{array}{l}\text { Mean Net } \\
\text { income } \\
\left(\text { Rs. ha }^{-1}\right)\end{array}$ & $\begin{array}{c}\text { Mean } \\
\text { B:C } \\
\text { ratio }\end{array}$ & $\begin{array}{c}\text { Extensio } \\
\text { n gap } \\
\left.(\mathbf{q ~ h a})^{-1}\right)\end{array}$ & $\begin{array}{c}\text { Technolo } \\
\text { gy gap } \\
\left(\mathbf{q ~ h a} \mathbf{~}^{-1}\right)\end{array}$ & $\begin{array}{l}\text { Techn } \\
\text { ology } \\
\text { index }\end{array}$ \\
\hline 1 & $\begin{array}{l}\text { Farmer's } \\
\text { practice }\end{array}$ & 51 & $952 \mathrm{~kg}$ & 33320 & -6180 & $0.84: 1$ & \multirow[t]{6}{*}{1.44} & \multirow[t]{6}{*}{6.29} & \multirow[t]{6}{*}{31.4} \\
\hline 2 & $\begin{array}{l}\text { Demonstratio } \\
\text { n practice }\end{array}$ & 51 & $1371 \mathrm{~kg}$ & 47985 & 15985 & $1.50: 1$ & & & \\
\hline & \multirow{2}{*}{\multicolumn{2}{|c|}{ Std. Deviation }} & 164 & 5750 & -5819 & & & & \\
\hline & & & 279 & 9784 & 15976 & & & & \\
\hline & t- value & & $8.9 * *$ & $8.9 * *$ & $13.7 * *$ & & & & \\
\hline & $\mathrm{p}$ - value & & 0.00 & 0.00 & 0.00 & & & & \\
\hline
\end{tabular}

(** significant at 1 percent level) 
Table.3 Extension and capacity building activities organized during cluster front line demonstrations during 2015-16

\begin{tabular}{|c|l|l|c|}
\hline S.No & \multicolumn{1}{|c|}{$\begin{array}{c}\text { Extension Activities } \\
\text { Organized }\end{array}$} & Date and Place of Activity & $\begin{array}{c}\text { Number of } \\
\text { Farmer } \\
\text { Attended }\end{array}$ \\
\hline $\mathbf{1}$ & $\begin{array}{l}\text { Pre-season training on } \\
\text { Integrated Crop Management } \\
\text { practices in sunflower } \\
\text { cultivation }\end{array}$ & $\begin{array}{l}\text { Kumarampalli on 02-01- } \\
2016\end{array}$ & 42 \\
\hline $\mathbf{2}$ & $\begin{array}{l}\text { Method demonstration on Soil } \\
\text { Application of Trichoderma } \\
\text { viride and PSB }\end{array}$ & Kumarampalli on 7-01-2016 & 22 \\
\hline $\mathbf{3}$ & $\begin{array}{l}\text { Result demonstration of Sulphur } \\
\text { and Boron fertilization }\end{array}$ & Kumarampalli on 7-01-2016 & 18 \\
\hline $\mathbf{4}$ & $\begin{array}{l}\text { Result Demonstration of } \\
\text { Thinning in sunflower }\end{array}$ & $\begin{array}{l}\text { Kumarampalli \& } \\
\text { Jogireddypalli on 25-1-2016 }\end{array}$ & 30 \\
\hline $\mathbf{5}$ & $\begin{array}{l}\text { Mid-season training programme } \\
\text { about Necrosis management in } \\
\text { sunflower }\end{array}$ & Kumarampalli \& 23-01-16 & 27 \\
\hline $\mathbf{6}$ & Monitoring team visit & Kumarampalli \& 28-01-16 & 40 \\
\hline $\mathbf{7}$ & Field day & Kumarampalli \& 12 -04-16 & 30 \\
\hline
\end{tabular}

\section{Photographs}






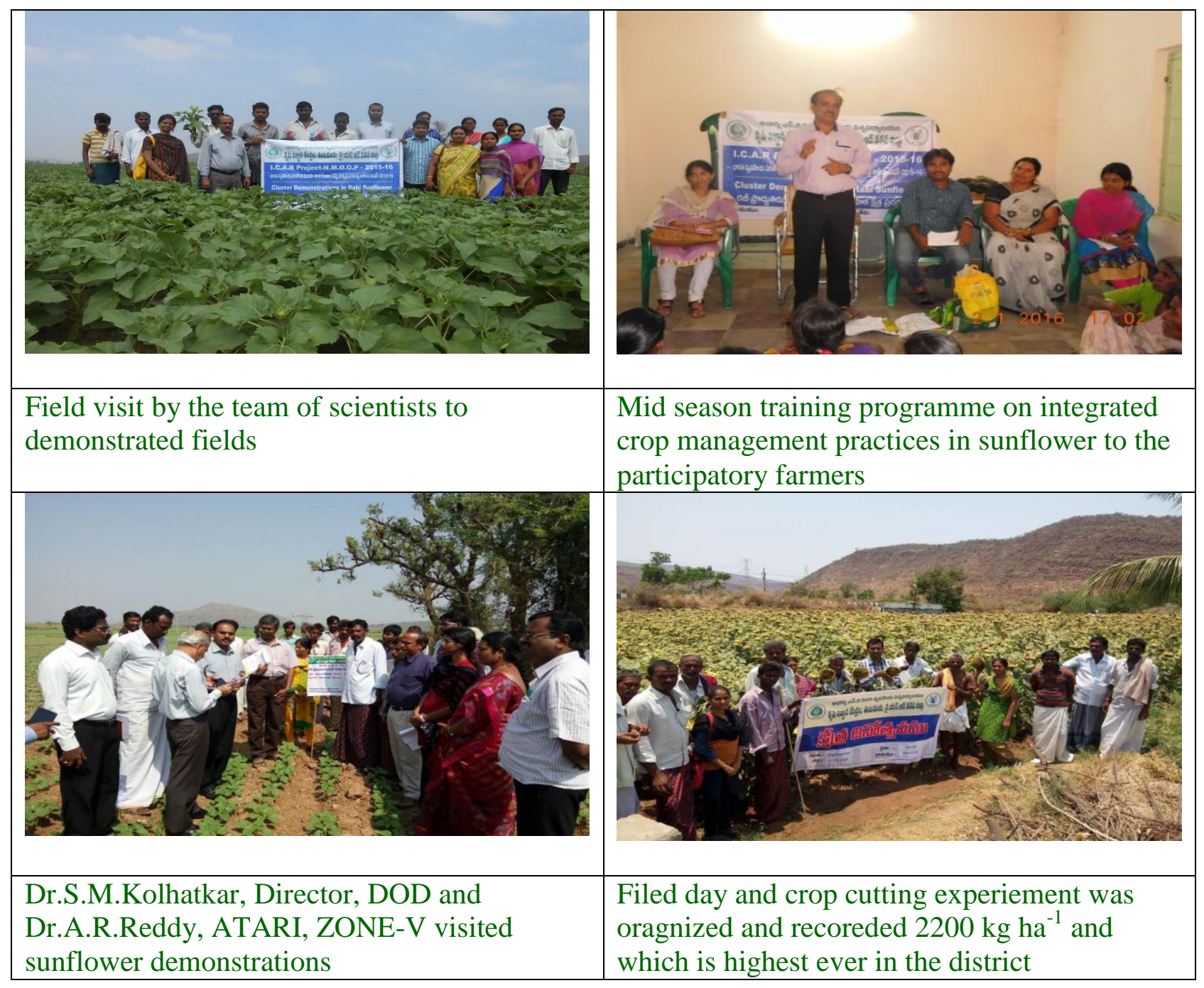

The extension gap for sunflower in the district is $1.44 \mathrm{q} \mathrm{ha}^{-1}$ and technology gap is still around $6.29 \mathrm{q} \mathrm{ha}^{-1}$ where as technology index is 31.4 it indicates there is greater scope for productivity enhancement by implementing technological interventions in sunflower. The best management practices demonstrated farmer's incurred 23.4 percent less cost on cultivation compared with farmer's practice (Rs.39,500 ha-1) cost of cultivation. The average gross returns of Rs. 47,985 $\mathrm{ha}^{-1}$ was recorded in demonstrations and which is about 30.5 percent higher than the farmer's practice (Rs.33,320 ha $\mathrm{ha}^{-1}$ ) with B:C ratio of 1.50:1 and 0.84:1 respectively which indicates negative returns of Rs. $6180 \mathrm{ha}^{-1}$ recorded in farmer's practice due to low yields coupled with increased cost of cultivation. The monitoring team of Dr.S.M.Kolhatkar, Director, DOD, Ministry of Agriculture, GOI and Dr.A.R.Reddy, ATARI, ZONE-V visited the demonstrated sites and observed the implementation of best management practices in farmers fields. Farmers expressed satisfaction pertaining to critical inputs provided and technical knowhow throughout the demonstrations. The yield and cost economics pertaining to the demonstrations are furnished hereunder.

Cluster frontline demonstration in sunflower organized in KVK operational villages of Y.S.R district and result concluded that average yield $1371 \mathrm{~kg} \mathrm{ha}^{-1}$ was recorded in 
Best Management Practices (BMP's) demonstrated fields as compared to $952 \mathrm{~kg} \mathrm{ha}^{-}$ ${ }^{1}$ recorded farmer's practice plot. This was 30.5 percent increase in yield over farmers practice $\left(952 \mathrm{~kg} \mathrm{ha}^{-1}\right)$ and 69.8 percent and 110 percent higher than the district average (809 $\mathrm{kg} / \mathrm{ha})$ and state average productivity $(650$ $\mathrm{kg} / \mathrm{ha}$ ) respectively.

The extension gap for sunflower in the district is $1.44 \mathrm{q} \mathrm{ha}^{-1}$ and technology gap is still around $6.29 \mathrm{q} \mathrm{ha}^{-1}$ where as technology index is 31.4 it indicates there is greater scope for productivity enhancement by implementing best technological interventions in sunflower through demonstrations and capacity building.

The successful implementation of frontline demonstration and various extensions activities like training programme, field day, exposure visit organized in CFLDs programmes in the farmer's fields leads to horizontal spread of BMP's to the other sunflower growing tracts of Rayalaseema region

\section{References}

Das Mamoni, Puzari N N and Ray B K 2010. Impact of training of skill and knowledge development of rural women, Agricultural Extension Review, 1(1): 29-30

Nayak, A., Gracy, C.P., Nagashree, N., Girisha, K.. 2010. An overview of Sunflower in India. KrishiSeva.com.

Hegde, D.M., Sudhakara Babu, S.N., 2009. Declining factor productivity and improving nutrient use efficiency in oilseeds. Indian Journal of Agronomy 54: $1-8$.

Samui S K, Maitra S, Roy D K, Mandal A K and Saha D (2000). Evaluation of frontline demonstration on groundnut. J Indian Soc Costal Agric Res 18 (2): $180-183$.

\section{How to cite this article:}

Madaka Madhan Mohan, S. Ramalakshmi Devi and Veeraiah, A. 2019. Demonstration of BMP's in Sunflower for Sustainable Yields under Black Soil Tracts of Rayalaseema Region of Andhra Pradesh, India. Int.J.Curr.Microbiol.App.Sci. 8(09): 2894- 2901. doi: https://doi.org/10.20546/ijcmas.2019.809.333 